\title{
Eritema nodozum: 33 hastanın klinik ve demografik özellikleri
}

\section{Erythema nodosum: The clinical and demographic characteristics of 33 patients}

\author{
Bilal Sula, Mustafa Arıca
}

\section{ÖZET}

Giriş: Kliniğimizde eritema nodozum tanısıyla takip ve tedavileri yapılan hastaların demografik ve klinik özelliklerinin belirlenmesi, etiyolojik faktörlerin araştırılması, laboratuvar bulguları ve tedavi rejimlerinin değerlendirilmesi amaçlanmıştır.

Yöntemler: Üniversitemiz Dermatoloji Kliniği'nde 20082014 yılları arasında yatırılıp takip edilen, klinik ve histopatolojik olarak eritema nodozum tanısı almış 33 hasta retrospektif olarak değerlendirildi.

Bulgular: Çalışmaya alınan hastaların yaşları 11 ile 69 yıl arasında olup ortalama yaş $40,57 \pm 13,98$ yıl olarak bulundu. Hastalar en çok 30-39 yaş aralığında $(\% 33,3)$ saptandı. Hastaların 29'u (\%87,9) kadın, 4'ü $(\% 12,1)$ erkek idi. Lezyonların en sık yerleşim yeri \%54,5 ile alt ekstremitelerde bulundu. Etiyolojide en sı \%30,3 ile enfeksiyonlar (Üst solunum yolu ve idrar yolu enfeksiyonları) görülürken bunu ilaçlar $(\% 12,1)$, gebelik $(\% 6,1)$, Behçet hastalığı $(\% 6,1)$ ve Sarkoidoz $(\% 3,1)$ takip ediyordu. Ortalama hastalık süresi 12,60 gün olarak bulundu. Hastaların \%72,7'si ilk atak şeklinde başvurmuştu. Ortalama hastanede yatış süresi 8,93 gün olarak bulundu.

Sonuç: Eritema nodozumda etiyoloji ülkeden ülkeye farklılık göstermekte olup çalışmamızda en sık idiopatik $(\% 42,4)$ olarak bulundu. Ancak tüm çalışmalarda etiyolojik faktörler benzer olup sadece sıralamada farklılık gösteriyordu. Klinik, laboratuvar, histopatolojik bulgular ve tedavi uygulamaları arasında belirgin bir farklılık görülmedi.

Anahtar kelimeler: Eritema nodozum, etiyoloji, klinik, demografi, tedavi

\section{GíRiş}

Eritema nodozum (EN) en s1k görülen ve en iyi bilinen pannikülit formudur. Tipik olarak akut, yuvarlak veya oval, ağrılı, ülsere olmayan, 1-6 cm çaplarında, pretibial alan üzerinde bilateral olarak yerleşmiş, eritemli subkutan nodüllerle karakterizedir. Lezyonlar 3-6 hafta içinde atrofi veya skar bırakmaksızın çürük benzeri bir hiperpigmentasyon

\begin{abstract}
Objective: In this study our aim was to determine demographic and clinical features, etiological factors, laboratory findings and treatment regimens of patients who were diagnosed and treated with erythema nodosum.
\end{abstract}

Methods: Thirty-three patients who were clinical and histopathological diagnosed as erythema nodosum in dermatology clinic of our university, dated between 2008 and 2014, were evaluated retrospectively.

Results: The study population consisted of 29 (87.9\%) female and $4(12.1 \%)$ male, with a mean age of $40.57 \pm 13.98$ years (range, 11-69 years). Most patients were found in the 30-39 age range. The most frequent localization of lesions was found in the lower extremities (54.5\%). Infections $(30.3 \%)$ were the most common identified etiologic factors followed by drugs (12.1\%), pregnancy $(6.1 \%)$, Behcet's disease $(6.1 \%)$ and sarcoidosis $(3.1 \%)$. The mean duration of disease was 12.60 days. $72.7 \%$ of patients were admitted as the first episode. The mean hospitalization time was 8.93 days.

Conclusion: The etiology of erythema nodosum varies from country to country. The most common etiological factor was found idiopathic (42.4\%) in our study. However, etiologic factors are similar in all studies, only showed differences in the rankings. No showed significant difference between clinical, laboratory, histopathological findings and treatment.

Key words: Erythema nodosum, etiology, clinic, demographic, treatment

bırakarak iyileşirler. Eski lezyonlar ve yeni lezyonlar bir arada görülebilir [1,2]. Herhangi bir yaşta görülebilse de en sık 2.- 4. dekadlarda görülür. Yapılan çalışmalarda kadınlarda erkeklerden 3-6 kat daha sı1k görüldügü gösterilmiştir. Bütün ırklarda görülebilir [1,3]. Bakteri, virüs ve kimyasal maddeler gibi antijenik uyaranlara karşı gecikmiş bir hipersensitivite reaksiyonu olduğu kabul edilmektedir [1] Etiyolojide enfeksiyonlar, ilaçlar, maligniteler, sis- 
temik inflamatuvar hastalıklar ve gebeliğin olduğu oldukça geniş bir spektrum vardır. Bununla beraber genellikle idiopatik görülmektedir [1,2]. Histopatolojik olarak subkutan doku ve derin dermiste vaskülitsiz septal pannikülit görülürken epidermis normal görünümdedir. Erken dönem lezyonlarda nötrofilik perivasküler reaksiyon gözlenir. Geç dönem lezyonlarda fibrozis, periseptal granülasyon dokusu, lenfositler ve multinükleer dev hücreler görülür. Ayrıca periferik dolaşımda artmış nötrofil dolaşımı reaktif oksijen üretimini artırarak doku hasarına yol açmaktadır [2-4].

Bu çalışmada kliniğimizde EN tanısıyla tanı, takip ve tedavileri yapılan hastaların demografik ve klinik özelliklerinin belirlenmesi, etiyolojik faktörlerin araştırılması, laboratuvar bulguları ve tedavi rejimlerinin değerlendirilmesi amaçlanmıştır.

\section{YÖNTEMLER}

Çalışmamızda 2008-2014 yılları arasında üniversitemiz dermatoloji kliniğinde yatırılıp takip edilen, klinik ve histopatolojik olarak EN tanısı almış toplam 33 hasta retrospektif olarak değerlendirildi. Hasta verileri epikriz ve hasta dosyaları taranarak elde edildi. Olgularda yaş, cinsiyet, EN süresi, EN başlangıç yaşı, eşlik eden hastalık, lezyonların yerleşim yeri, atak sayısı, laboratuvar bulguları ve uygulanan tedaviler değerlendirildi. Hastalarda EN etiyolojisine yönelik olarak yapılan tam kan sayımı, Eritrosit sedimentasyon hızı (ESH), antistreptolizin-O (ASO), C-reaktif protein (CRP) ve romatoid faktör (RF) düzeyleri, paterji testi, karaciğer Fonksiyon testleri (KCFT), böbrek fonksiyon testleri, salmonella ve brusella serolojisi, boğaz-kan ve idrar kültür sonuçları, tam idrar tahlili, hepatit markırları, antinükleer antikor (ANA) sonuçları değerlendirildi. Gerekli durularda tümör markırları, periferik yayma ve batın-pelvik ultrasonografi yapıldı. Lökosit sayısı $>10.200 / \mathrm{mm}^{3}$, Ateş $>37,7^{\circ} \mathrm{C}$, ESH $>20 \mathrm{~mm} / \mathrm{saat}, \mathrm{CRP}>0.8 \mathrm{mg} / \mathrm{dL}, \mathrm{ALT}>35 \mathrm{U} / \mathrm{L}$, AST $>40 \mathrm{U} / \mathrm{L}$ ve PPD $>10 \mathrm{~mm}$ değerleri patolojik kabul edildi. Başvuru tarihinden dört hafta öncesine kadar tanımlanan ilaçlar ve streptokokal enfeksiyonlar ile bir hafta öncesine kadar tanımlanan viral enfeksiyonlar veya gribal enfeksiyon gibi üst solunum yolları enfeksiyonları (ÜSYE), boğaz kültürünün pozitif olması veya ASO titresinin yüksek bulunması etiyolojik faktörler (poststreptokokal EN) olarak kabul edildi. Tüberküloz tanısı akciğer grafisi,
PPD, balgamda ARB ve göğüs tüberküloz bölümü ile beraber değerlendirilerek konuldu. Sarkoidoz tanısı klinik, radyolojik ve histopatolojik bulguların varllğı ve gögüus tüberküloz kliniği ile konsültasyon sonucuna göre yapıldı. Behçet hastalığ tanısı Uluslararası Behçet Çalışma Grubunun tanı kriterleri ile konuldu. EN'nin en az bir aylık iyileşme süreci sonrasında tekrarlaması atak olarak kabul edildi. Tüm olgularda EN lezyonlarına ve sekonder olgularda altta yatan hastalığa yönelik tedaviler uyguland1. Lezyonlarda ortalama 1-2 hafta içinde gerileme olan hastalar tedavileri düzenlendikten sonra taburcu edildi ve kontrole çağrıldı.

İstatistiksel analiz hesaplamaları SPSS 15.0 programı ile yapıldı. Sürekli değişkenler ortalama \pm $\mathrm{SD}$, kategorik değişkenler ise \% olarak belirtildi. Kategorik ve sürekli değişkenlerin karşılaştırılmasında ki-kare testi kullanıldı. İstatistiksel değerlendirmelerde $\mathrm{p}<0,05$ olan değerler anlamlı kabul edildi.

\section{BULGULAR}

Çalışmaya alınan hastaların yaşları 11 ile 69 yıl arasinda olup ortalama yaş $40,57 \pm 13,98$ yıl olarak bulundu. Hastalar en çok 30-39 yaş aralığında $(\% 33,3)$ ve 40-49 yaş aralığında $(\% 27,3)$ saptandı. Hastaların 29'u (\%87,9) kadın, 4'ü $(\% 12,1)$ erkek idi. EN Kadınlarda 7,25 kat daha sık görüldü. Lezyonların en s1k yerleşim yeri \%54,5 ile alt ekstremiteler iken $\% 45,5$ 'inde hem alt ekstremitelerde hem de üst ekstremitelerde lezyon vard1. Etiyolojide en s1k \%30,3 ile enfeksiyonlar (ÜSYE ve idrar yolu enfeksiyonlar1) görülürken bunu ilaçlar $(\% 12,1)$, gebelik $(\% 6,1)$, Behçet hastalığ $(\% 6,1)$ ve Sarkoidoz $(\% 3,1)$ takip ediyordu. İlaçlara bağlı EN olan hastalarda 3 hastada oral antibiyotik ve analjezik kullanımı, 1 hastada oral kontraseptif kullanımı öyküsü mevcuttu. Hastaların \%42,4'ünde etiyolojik faktör saptanamadi. Hastalarda sistemik bulgu olarak ateş $(n=8)$, artralji $(\mathrm{n}=5)$, halsizlik $(\mathrm{n}=7)$ ve öksürük $(\mathrm{n}=3)$ saptand1. Laboratuvar sonuçlarında lökositoz $(\% 48,5)$, CRP yüksekliği $(\% 81,8)$, Sedimentasyon yüksekliği $(\% 81,8)$, ASO yüksekliği $(\% 33,3)$ ve KCFT'inde yükseklik $(\% 9,1)$ saptand. Hastalık süresi 2 ile 25 gün arasında değişmekte olup ortalama hastalık süresi 12,60 gün olarak bulundu. Rekürrens sıkl1ğ 1-6 atak arasında olup ortalama 1,84 atak olarak bulundu. Hastaların \%72,7'sinde ilk atak şeklinde başvuru olmuştu. Hastanede yatış süreleri 3-35 gün arasinda olup ortalama 8,93 gün olarak bulundu. 
Tedavi olarak hastalara etiyoloji ve bulgulara göre kolşisin, sistemik steroid, potasyum iyodür, nonsteroid antiinflamatuvar ilaçlar (NSAIII) ve antibiyotik tedavileri ve bunların kombinasyonları verildi. Hastaların demografik ve klinik verileri tablo 1'de özetlenmiştir.

Tablo 1. Hastaların demografik ve klinik verileri

\begin{tabular}{|c|c|c|}
\hline Parametreler & Hasta (n) Ort $\pm S D$ & $\%$ \\
\hline $\begin{array}{l}\text { Yaş (yıl) } \\
\text { Yatış süresi (gün) } \\
\end{array}$ & $\begin{array}{c}40.57 \pm 13.98 \\
8.93 \pm 6.40 \\
\end{array}$ & \\
\hline $\begin{array}{l}\text { Cinsiyet } \\
\text { Kadın } \\
\text { Erkek }\end{array}$ & $\begin{array}{c}29 \\
4\end{array}$ & $\begin{array}{l}87.9 \\
12.1\end{array}$ \\
\hline $\begin{array}{l}\text { Eşlik eden hastalık } \\
\text { Hipertansiyon } \\
\text { Rekürren aftöz stomatit } \\
\text { Bronşiektazi } \\
\text { Astım } \\
\text { Üveit } \\
\text { Down Sendromu }\end{array}$ & $\begin{array}{l}4 \\
2 \\
1 \\
1 \\
1 \\
1\end{array}$ & $\begin{array}{c}12.1 \\
6.1 \\
3 \\
3 \\
3 \\
3\end{array}$ \\
\hline $\begin{array}{l}\text { Lokalizasyon } \\
\text { Alt ekstremite } \\
\text { Üst ve alt ekstremite }\end{array}$ & $\begin{array}{l}18 \\
15 \\
\end{array}$ & $\begin{array}{l}54.5 \\
45.5\end{array}$ \\
\hline $\begin{array}{l}\text { Etiyoloji } \\
\text { İdiyopatik } \\
\text { Enfeksiyon } \\
\text { İdrar yolu enfeksiyonu } \\
\text { İlaçlar } \\
\text { Gebelik } \\
\text { İnflamatuar hastalık } \\
\text { Sarkoidoz } \\
\text { Behçet hastalığı } \\
\text { Atak sayısı } \\
\text { Hastalık süresi (gün) }\end{array}$ & $\begin{array}{c}14 \\
10 \\
3 \\
4 \\
2 \\
1 \\
2 \\
1.84 \pm 1.67 \\
12.60 \pm 4.98\end{array}$ & $\begin{array}{c}42.4 \\
30.3 \\
9.1 \\
12.1 \\
6.1 \\
\\
3 \\
6.1\end{array}$ \\
\hline $\begin{array}{l}\text { Sistemik Bulgular } \\
\text { Ateş } \\
\text { Atralji } \\
\text { Halsizlik } \\
\text { Öksürük }\end{array}$ & $\begin{array}{l}8 \\
5 \\
7 \\
3 \\
\end{array}$ & $\begin{array}{c}24.2 \\
15.2 \\
21.2 \\
9.1 \\
\end{array}$ \\
\hline $\begin{array}{l}\text { Laboratuvar Bulgusu } \\
\text { Lökositoz } \\
\text { Sedim yüksekliği } \\
\text { CRP yüksekliği } \\
\text { ASO yüksekliği } \\
\text { KCFT yüksekliği }\end{array}$ & $\begin{array}{l}16 \\
27 \\
27 \\
11 \\
3\end{array}$ & $\begin{array}{l}48.5 \\
81.8 \\
81.8 \\
33.3 \\
9.1\end{array}$ \\
\hline $\begin{array}{l}\text { Tedavi } \\
\text { Kolşisin } \\
\text { Sistemik kortikosteroid } \\
\text { Potasyum iyodür } \\
\text { NSAil } \\
\text { Antibiyotik }\end{array}$ & $\begin{array}{c}13 \\
14 \\
2 \\
25 \\
20\end{array}$ & $\begin{array}{c}39.4 \\
42.4 \\
6.1 \\
75.8 \\
60.6\end{array}$ \\
\hline
\end{tabular}

Ort \pm SD: Ortalama \pm Standart deviasyon, NSAil: Non-steroid anti-inflamatuar ilaç

\section{TARTIŞMA}

Eritema nodozum çeşitli uyaranların tetiklediği reaktif bir süreç olup klinik olarak en sık görülen septal pannikülittir. Genç kadınlarda daha sık görülmektedir. 20-30 yaş arasında pik yapar [3,5]. Vakaların \%55'i idiopatik olup en s1k nedenler enfeksiyonlar (streptokok, tüberküloz, yersiniyozis, üst solunum yolu enfeksiyonları), ilaçlar (oral kontraseptifler, penisilin, sülfonamidler), sarkoidoz, İnflamatuar bağırsak hastalıklarından (İBH), gebelik ve Hodgkin lenfoma gibi malignitelerdir. Altta yatan hastalıklar coğrafik bölgeye göre farkl1lık gösterebilir $[1,2]$. Çocuklarda en s1k etiyolojik faktör coğrafik bölgeye bağlı endemik enfeksiyonlar ve streptokokal enfeksiyonlar iken yetişkinlerde ilaçlar, sarkoidoz ve İBH'dır $[4,5]$. EN patogenezi tam olarak anlașılamamıștır, fakat subkutan yağ dokusu septumlarının venüllerinde immün komplekslerin birikimi sonucu olduğu düşünülmektedir. Ayrıca genetik bir eğilim de vardır [5]. Ani başlayan, simetrik, hassas, eritemli, sıcak nodül ve plaklar oldukça karakteristiktir. Lezyonlar en s1k bacaklara yerleşim gösterir. Bunun dişında uyluk ve önkollarda sıklıkla tutulur. Gövde, boyun ve yüz tutulumu nadirdir. Diğer pannikülitlerden farklı olarak ülserasyon görülmez. Akut ataklarda ateş, yorgunluk, atralji, başağrıs1, öksürük, karın ağrısı, bulantı veya diyare görülebilir. Episkleral lezyonlar ve konjoktivit'de eşlik edebilir $[1,3]$. Lezyonlar birkaç gün veya haftadan sonra skar bırakmadan, çürük rengi bir hiperpigmentasyon birakarak, yavaş yavaş iyileşmeye başlar [1]. EN'un spesifik bir tedavisi olmayıp eğer altta yatan bir hastalık varsa buna göre planlanır. Yatak istrahati ile birlikte NSAIII (indometazin ya da naproksen), potasyum iyodür (günde $3 \mathrm{kez}$, suya veya portakal suyuna, 2-10 damla, günlük 400-900 $\mathrm{mg}$ ), sistemik steroidler, kolşisin, dapson, hidroksiklorokin, metotreksat, talidomid ile son dönem çalışmalarda özellikle aktif İBH olanlarda biyolojik ajanların kullanımı yer almaktadır [3-5].

Öz ve ark'larının 2012 yılında, EN'li 66 hastada yaptığı çalışmada; hastaların yaşları 7-81 arasinda (ortalama 42,22 $\pm 16,03$ ) ve kadinlarda 2,5 kat daha sık olduğu bildirilmiş. Etiyolojide en sık Behçet hastalığı, ilaç (aspirin, asetominofen, NSAIII, oral kontraseptifler, atenolol vs.), sarkoidoz, ÜSYE, otoimmun hastalık, gebelik ve tüberküloz bulunmuşken, Hastaların \%21'inde etiyoloji saptanama- 
mıştır. Etiyolojisi belli olan hastalarda CRP ve ESR yüksekliği, RF ve ASO pozitifliği görülmüş. Tedavi olarak hastalara NSAIII $(n=9)$, kolşisin $(n=14)$,steroid ( $\mathrm{n}=4$, Behçet hastalığ 1$)$, interferon $(n=1)$ ve azotiyopürin $(\mathrm{n}=1)$ verilmiş ve hastaların $\% 16$ 'sında spontan gerileme görülmüştür [6].

Adışen ve ark.'larının EN tanılı 72 hastada yaptığ 1 çalışmada yaş ortalaması $40,16, \mathrm{~K} / \mathrm{E}=2,4$ olarak saptanmıştır. Hastaların \%41,6'sında herhangi bir etiyolojik faktör bulunmazken, etiyolojide en s1k $\% 33,3$ ile enfeksiyonlar ve bunun dişında Behçet hastalığı, ilaçlar, sarkoidoz ve gebelik bulunmuştur. Hastaların \%76,8'inde tek atak, \%18'inde 2'den fazla atak olduğu, lezyonların en sik bacaklarda (\%93) yerleşim gösterdiği bildirilmiştir. Laboratuvar değerlerinde lökositoz (\%33,3), ESH yüksekliği $(\% 65,2)$, ASO yüksekliği $(\% 18)$, CRP yüksekliği $(\% 31,9)$ ve PPD pozitifliği bulunmuştur [7].

Mert ve ark'larının yaptı̆̆ hasta değerlendirilmiştir. Yaş ortalaması 38 ve kadınlarda 6 kat daha sık bulunmuştur. Hastaların \%54'ünde etiyolojik sebep saptanmıştır. En sık poststreptokokal, sarkoidoz, İBH, Behçet hastalığ ve gebelik tespit edilmiş olup hastalarda anormal akciğer grafisi, lökositoz, ESH ve CRP yüksekliği gibi laboratuvar değişiklikleri ile ateş, öksürük, boğaz ağrısı gibi sistemik bulgular bildirilmiştir [8].

Otuzdokuz EN'li çocuk hastada yapılan bir çalışmada 21 kadın 18 erkek toplam 39 hasta değerlendirilmiştir. Hastaların \%62'si 7-12 yaş aralığında olup ortalama yaş 11,3 , ortalama hastalık süresi 6,6 gün olarak bulunmuştur. Hastaların \%56,4'ünde etiyoloji tespit edilmiş olup en s1k sırasıyla streptokokal enfeksiyon, tularemi, latent tüberküloz, pulmoner tüberküloz, Behçet hastalığı, Sitomegalovirüs Giardia lambiya ve sarkoidoz saptanmıştır. Hastalarda lökositoz (\%41), CRP yüksekliği $(\% 68,5)$ ve ESH (\%60) yüksekliği bulunmuştur [9].

Singapurda yapılan bir çalışmada; 4-70 yaş aras1 (en çok 21-30 yaş aralığı) 75 hasta değerlendirilmiş ve kadınlarda 6,5 kat daha sık görülmüştür. Etiyolojide en sık ÜSYE, tüberküloz, gebelik, Behçet hastalığ 1 , gonore, varisella saptanırken hastaların \%60'ında etiyoloji saptanamamıştır. Hastaların artralji (\%12), ateş (\%11), yorgunluk, iştahsızlık ve kilo kayb1 (\%7) görülürken geri kalan hastalarda (\%70) herhangi bir semptom saptanmamıştır. Labo- ratuvar değerlerinde 3 hastada beyaz küre yüksekliği, 11 hastada sedimentasyon yüksekliği, 7 hastada ASO yüksekliği, tüberkülozlu 2 hastada anormal akciğer grafisi ve pozitif Mantoux testi saptanmış. Hastalara tedavi olarak NSAIII ( $\mathrm{n}=40$, indometazin, mefenamik asit veya ibuprofen), potasyum iyodür $(n=11)$, kolşisin $(n=11)$, ve oral prednizolon $(n=18$, 20mg/gün, 7 gün) verilmiş ve bazı hastalarda kombine tedaviler uygulanmıştır. Hastaların çoğunda lezyonların 2-4 hafta içinde düzeldiği bildirilmiş [10]. Daoud ve ark.' larının 103 EN hastasında yapt1ğ1 çalışmada kadınlarda 5 kat daha fazla görülürken ortalama yaş 36,5 yıl olduğu bulunmuştur. Hastaların\%22,3'ünde etiyolojik bir neden bulunmamıştır. En s1k görülen etiyolojik sebepler sırasıyla poststreptokokal enfeksiyon, tüberkülozis, Crohn hastalığı, Behçet hastalığı ve sarkoidoz bulunmuş [11]. İtalya'da 2010 y1lında yapılan bir çalışmada 124 EN'li hastada ortalama yaş 39,5 y1l olarak saptanmıştır. Hastaların \%58,8'inde herhangi bir etiyoloji faktör saptanmıştır. Bunlar sırasıyla enfeksiyonlar, ilaçlar, sistemik hastalıklar ve gebelik olarak bildirilmiştir [12].

Çalışmamızda hastaların çoğu 30-39 yaş aralığında olup kadın/erkek oranı 7,25:1 olarak bulundu. Lezyonların en sik alt ekstremitelerde saptand1. Hastaların \%42,4'ünde etiyolojik bir faktör bulunmadi. Etiyolojisi saptananlarda sirasıyla en s1k enfeksiyonlar, ilaçlar, gebelik, Behçet hastalığı ve sarkoidoz bulundu. Hastalarda ateş, atralji, halsizlik ve öksürük gibi sistemik bulgular saptandı. Laboratuvar sonuçlarında lökositoz, CRP, sedimentasyon, ASO yüksekliği ve KCFT'sinde yükseklik saptand. Ortalama hastalık süresi 12,60 gün, rekürrens sıklığ 1 ortalama 1,84 olarak bulundu. Hastaların \%72,7'sinde ilk atak şeklinde başvurmuştu. Tüm çalışmalarda etiyolojik faktörler benzer olup sıralamada farkl1lık gösteriyordu. Klinik, laboratuvar, histopatolojik bulgular ve tedavi uygulamaları arasında belirgin bir farklılık görülmedi. Sonuç olarak çalışmamızdaki mevcut bulgular dünyanın farklı bölge ve ülkelerden bildirilen çalışmalarla benzerlik gösteriyordu.

\section{KAYNAKLAR}

1. Patterson JW. Panniculitis. In: Bolognia JL, Jorizzo JL, Schaffer JV editors. Dermatology. 3st ed. Elsevier 2012 p.1641-1645. 
2. Mana J, Marcoval J. Erythema nodosum. Clin Dermatol 2007;25:288-294.

3. Requena L, Yus ES. Panniculitis. Part I. Mostly septal panniculitis. J Am Acad Dermatol 2001;45:163-183.

4. Gilchrist H, Patterson JW. Erythema nodosum and erythema induratum (nodular vasculitis): diagnosis and management. Dermatol Ther 2010;23:320-327.

5. Blake T, Manahan M, Rodins K. Erythema nodosum - a review of an uncommon panniculitis. Dermatol Online J 2014;20:22376.

6. Öz A, Aydoğan K, Adım ŞB, et al. Erythema Nodosum Epidemiology: 5-Years Retrospective Study. Turk J Dermatol 2012;6:87-90.

7. Adışen E, Şeker Ü, Gürer MA. Etiologic Factors in Erythema Nodosum. Türkderm 2008;42:113 -117.
8. Mert A, Ozaras R, Tabak F, et al. Erythema nodosum: an experience of 10 years. Scand J Infect Dis 2004;36:424-427.

9. Teke TA, Tanır G, Bayhan GI, et al. Erythema nodosum in children: evaluation of 39 patients. Turk J Pediatr 2014;56:144-149.

10. Tay YK. Erythema nodosum in Singapore. Clin Exp Dermatol 2000;25:377-380.

11. Daoud L, El Euch D, Ben Tekaya N, et al. Erythema nodosum: profile in a Tunisian teaching hospital. Tunis Med 2007;85:1020-1024.

12. Papagrigoraki A, Gisondi P, Rosina P, et al. Erythema nodosum: etiological factors and relapses in a retrospective cohort study. Eur J Dermatol 2010;20:773-777. 